ELECTIONS AND VOTING BEHAVIOUR IN BRITAIN 


\section{CONTEMPORARY POLITICAL STUDIES SERIES}

Series Editor: John Benyon, Director, Centre for the Study of Public Order, University of Leicester

A series which provides authoritative yet concise introductory accounts of key topics in contemporary political studies.

Other titles in the series include:

Pressure Groups, Politics and Democracy in Britain

WYN GRANT, University of Warwick

UK Political Parties since 1945

Edited by ANTHONY SELDON, Institute of Contemporary British

History

Politics and Policy Making in Northern Ireland

MICHAEL CONNOLLY, University of Ulster

Local Government and Politics in Britain

JOHN KINGDOM, Sheffield Polytechnic

British Political Ideologies

ROBERT LeACH, Leeds Polytechnic

British Government: The Central Executive Territory

PETER MADGWick, Professor Emeritus, Oxford Polytechnic

Race and Politics in Britain

SHAMIT SAGGAR, Queen Mary and Westfield College, University

of London

Selecting the Party Leader

MALCOLM PUNNETT, University of Strathclyde

Does Parliament Matter?

PHILIP NORTON, University of Hull

The President of the United States

DAVID MERVIN, University of Warwick

The Politics of Economic Policy

WYN GRANT, University of Warwick

Introduction to International Politics

DEREK HEATER, formerly of Brighton University and

G.R. BERRIDGE, University of Leicester 


\title{
ELECTIONS AND VOTING BEHAVIOUR IN BRITAIN
}

\author{
Second Edition
}

DAVID DENVER

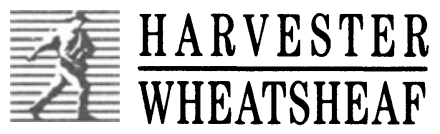

New York London Toronto Sydney Tokyo Singapore 


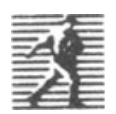

First published 1994 by Prentice Hall/Harvester Wheatsheaf

Campus 400, Marylands Avenue

Hemel Hempstead

Hertfordshire, HP2 7EZ

A division of

Simon \& Schuster International Group

C David Denver, 1994

All rights reserved. No part of this publication may be reproduced, stored in a retrieval system, or transmitted, in any form, or by any means, electronic, mechanical, photocopying, recording or otherwise, without prior permission, in writing, from the publisher.

Typeset in 10/12pt Times

by Dorwyn Ltd, Rowlands Castle, Hants.

British Library Cataloguing in Publication Data

A catalogue record for this book is available from the British Library

ISBN 978-0-333-73914-3 ISBN 978-1-349-14905-6 (eBook)

DOI 10.1007/978-1-349-14905-6

$\begin{array}{llllllll}4 & 5 & 6 & 7 & 00 & 99 & 98 & 97\end{array}$ 


\section{CONTENTS}

$\begin{array}{ll}\text { Preface to the first edition } & \text { ix }\end{array}$

Preface to the second edition

I THE STUDY OF ELECTIONS AND ELECTORAL BEHAVIOUR

Why study elections?

Analysing election results 4

Types of data 4

Sample surveys and the analysis of nominal data 6

The analysis of interval-scale data 14

Interpreting correlation coefficients 18

$\begin{array}{ll}\text { Measuring electoral change } & 19\end{array}$

Aggregate and survey data compared 23

Notes $\quad 25$

2 THE ERA OF ALIGNMENT 1950-70 27

Two models of voting behaviour $\quad 27$

Aligned voting in Britain 1950-70 31

Partisan alignment $\quad 32$

Class alignment $\quad 34$

Defining class $\quad 35$

Other social influences on voting 36

Explaining the 'deviants': working-class Tories 44 
$\begin{array}{ll}\text { Conclusion } & 48\end{array}$

$\begin{array}{ll}\text { Notes } & 50\end{array}$

3 PARTISAN AND CLASS DEALIGNMENT AFTER 1970

Partisan dealignment $\quad 53$

Explaining partisan dealignment $\quad 55$

Class dealignment $\quad 60$

Explaining class dealignment $\quad 62$

The debate over class dealignment $\quad 67$

How Britain Votes: a revisionist view 67

Understanding Political Change: the debate continued 72

The consequences of dealignment: electoral volatility 73

$\begin{array}{ll}\text { Other social characteristics } & 78\end{array}$

Conclusion $\quad 83$

Notes $\quad 84$

4 ISSUE VOTING 85

Conditions for issue voting $\quad 86$

Issue voting in the era of alignment $\quad 87$

Measuring issue voting 89

Evidence of issue voting after 1970

Critics of issue voting $\quad 97$

Judgemental voting 101

The economy and voting $\quad 102$

$\begin{array}{ll}\text { Conclusion } & 105\end{array}$

$\begin{array}{ll}\text { Notes } & 106\end{array}$

5 PARTY LEADERS, ELECTION CAMPAIGNS AND THE MEDIA $\quad 107$

The impact of party leaders $\quad 108$

Election campaigns $\quad 112$

Local campaigns $\quad 115$

$\begin{array}{ll}\text { The national campaign } & 117\end{array}$

$\begin{array}{ll}\text { The effects of the media } & 119\end{array}$

$\begin{array}{ll}\text { Television } & 121\end{array}$

$\begin{array}{ll}\text { The press } & 124\end{array}$

$\begin{array}{lr}\text { Public opinion polls } & 129\end{array}$

Conclusion $\quad 135$

$\begin{array}{lr}\text { Notes } & 135\end{array}$ 
6 TRENDS IN GENERAL ELECTION RESULTS 136

Turn-out

Patterns of party support 1950-70

144

Patterns of party support 1970-87

Conclusion

160

Notes

7 THE 1992 GENERAL ELECTION AND THE ELECTORAL OUTLOOK

The 1992 election

Variations in swing

The electoral system

Social groups and party choice

Judgemental voting

The electoral outlook

171

The Conservatives

172

Labour

174

Liberal Democrats

Conclusion

Notes

Bibliography

Index 


\section{PREFACE TO THE FIRST EDITION}

Elections in Britain, as in all liberal democracies, are central to the political process. They involve, to some extent, almost the entire adult population and inform almost every aspect of political life. Not surprisingly, interest in elections is also widespread - from students and teachers of British politics at school or undergraduate level to journalists, members of political parties and many otherwise 'ordinary' people. The problem for people like these is that in recent years the specialised literature dealing with elections and voting behaviour in Britain has grown enormously and has become highly technical and statistically complex.

My intention in this book is to introduce readers to this wider literature in a way that is as non-technical as I can make it. I hope that there is enough 'meat' in the book to satisfy undergraduates and A-level students but I hope, too, that those whose interest in the subject is more general will find the book rewarding. With this audience in mind, I have had to simplify some rather complicated material and I apologise in advance to any of the authors discussed who may think that I have over-simplified their arguments, theories or conclusions. Really serious students of electoral analysis must consult the primary literature themselves.

Talking about, reading about, observing, participating in and even doing research on elections are not just for 'serious students', however. If any readers who are not currently students acquire from this book a fuller understanding of trends in British elections 
and a keener, more critical interest in the electoral process then it will have served one of its major purposes.

Preparing the book has, of course, involved me in numerous debts. I am grateful to the following for permission to reproduce material: American Enterprise Institute, Butterworth Scientific Ltd, Cambridge University Press, David Butler, Ivor Crewe, Colin Crouch, Patrick Dunleavy, Anthony Heath and William Miller.

Jeremy Mitchell commented helpfully on an early draft of the manuscript and John Bochel also gave me the benefit of his sage advice. Russell Price, with his enviable eye for detail, made numerous useful suggestions on points of style. I am especially grateful to my colleague Gordon Hands who read and re-read numerous drafts and with whom I have had lengthy and profitable discussions at every stage of writing. The general editor of the series, John Benyon, and Philip Cross of Philip Allan Ltd were valued sources of encouragement and advice. Finally, my wife Barbara not only supported and encouraged me and tolerated a good deal, but also mastered a new word processing system to prepare the manuscript.

Despite the best efforts of all of these, there remain, no doubt, errors of interpretation and (just possibly) fact. Responsibility for these is mine.

David Denver Lancaster, 1989 


\section{PREFACE TO THE SECOND EDITION}

The comments that I have received from colleagues about the first edition of the book have been generally encouraging. In this edition, therefore, the structure of the book is broadly the same, although I have taken the opportunity not only to update data and incorporate the most recent literature but also to include some new topics (e.g. volatility) and clarify my ideas on others.

I have received conflicting advice about the introductory statistical material in the first chapter but have decided to retain it as I think that some grasp of the basic ideas presented there is essential for understanding the rest of the book.

Almost anyone writing about British elections owes a debt of gratitude to the British Election Study team. The data from their surveys of the 1992 election have been made available with remarkable rapidity and the fact that $I$ have been able to use these data has made this edition much more valuable than would have been possible otherwise.

Finally, I should like to thank Clare Grist of Simon \& Schuster and June Rye for help of various kinds in the preparation of this edition.

David Denver

Lancaster, November 1993 